\title{
KOLIZJE STATKÓW POWIETRZNYCH Z PTAKAMI ROSNĄCYM ZAGROŻENIEM TRANSPORTU LOTNICZEGO
}

\author{
Bird Impact - a Growing Threat for Aviation
}

\author{
Столкновения воздушных судов с птицами \\ - растущая угроза для авиатранспорта
}

\begin{abstract}
Abstrakt
Cel: Identyfikacja zagrożeń związanych z następstwami kolizji statków powietrznych z ptakami oraz przedstawienie konsekwencji wypadków w wymiarze społecznym i finansowym.

Wprowadzenie: Zderzenia środków transportu powietrznego z małymi obiektami stanowią poważny problem dotyczący bezpieczeństwa pasażerów, ładunków i urządzeń technicznych. Wśród tego typu zdarzeń dominują zajścia z udziałem ptaków. W artykule przedstawiono zagrożenia, jakie w lotnictwie stwarzają kolizje statków powietrznych z ptakami oraz innymi obiektami, które przypadkowo mogą zostać uderzone przez szybko poruszający się samolot znajdujący się w powietrzu lub na pasie startowym. Metodologia: Zjawisko znane jako Foreign Object Damage przedstawiono w ujęciu historycznym ze szczególnym podkreśleniem trendów i tendencji kształtujących się we współczesnych realiach technicznych, przyrodniczych i organizacyjnych. W prezentowanej pracy przeprowadzono analizę przyczyn zwiększających prawdopodobieństwo zdarzeń zakończonych uderzeniem ptaka w elementy struktury statku powietrznego. Omówiono zagadnienia o dużym ryzyku wypadkowym związane ze wzrostem natężenia ruchu lotniczego i przystosowaniem ptaków do warunków środowiskowych panujących wokół lotnisk. Przedstawiono informacje dotyczące liczby kolizji oraz ich związku ze zidentyfikowanymi przyczynami. Analizę przeprowadzono dla danych dotyczących lotnictwa cywilnego oraz lotnictwa wojskowego ze szczególnym uwzględnieniem informacji pochodzących z USA i Wielkiej Brytanii. Przedstawiono metody ograniczania ryzyka wystąpienia kolizji statku powietrznego z ptakiem. Omówiono skuteczność i efektywność ekonomiczną działań podejmowanych w celu zarządzania środowiskiem naturalnym na terenach lotnisk. Podkreślono rolę, jaką w ograniczaniu ryzyka pełnią międzynarodowe przepisy definiujące minimalne normy, wymagania i procedury regulujące zasady projektowania, produkcji, obsługi technicznej, użytkowania sprzętu lotniczego oraz licencjonowania personelu.

Wnioski: Kolizje statków powietrznych z ptakami są problemem globalnym i dotyczą wszystkich podmiotów związanych z lotnictwem. Sformułowano tezę, że największy potencjał w długofalowych działaniach zmierzających do zmniejszenia zagrożenia wynikającego z kolizji statku powietrznego z ptakiem tkwi w rozwoju bezpiecznych konstrukcji płatowców i silników rozpraszających oraz pochłaniających energię uderzenia oraz wspomagających podejmowanie decyzji przez personel naziemny i załogi statków powietrznych naziemnych i pokładowych systemów umożliwiających monitoring i predykcję ptasich zachowań.
\end{abstract}

Słowa kluczowe: bezpieczeństwo lotów, samoloty, koszty, ptaki, zderzenia

Typ artykułu: artykuł przeglądowy

\begin{abstract}
Aim: Identification of risks following collisions between aircraft and birds, and exposure of socio-economic consequences after such incidents.

Introduction: Aircraft collisions, with small objects, present a serious problem in connection with the safety of passengers, cargo and technical equipment. Most common incidents involve collisions with birds. This article presents emerging hazards caused by birds and other small objects, which collide with fast moving aircraft in the air or on the runway.

Methodology: Incidents known as "Foreign Object Damage" are illustrated historically with a particular emphasis on emerging trends found in current technical, environmental and organisational circumstances. The author analysed causes leading to the increased probability of bird collisions with aircraft and examined issues associated with the high risk of accidents aligned with an increase in air traffic volume and bird acclimatisation to prevailing environments in the vicinity of airports. The article contains data about frequency
\end{abstract}

\footnotetext{
${ }^{1}$ Instytut Technologii Eksploatacji - Państwowy Instytut Badawczy, ul. K. Pułaskiego 6/10, 26-600 Radom, andrzej.zbrowski@itee.radom.pl / Institute for Sustainable Technologies - National Research Institute, Radom, Poland;
} 
of collisions and associated causes. An analysis was performed on data in respect of civil as well as military aviation, with a particular emphasis placed on information derived from USA and Great Britain. The author described approaches to minimise the risk of collision between aircraft and birds, and discussed the economical effectiveness of actions undertaken to manage the environment surrounding airports. The article highlights the role performed by international provisions covering risk mitigation, which define minimum norms, requirements and procedures regulating aircraft design, manufacturing processes, technical support, equipment use and awarding of licences to staff.

Conclusions: The collision of aircraft with birds is a global problem and involves all elements associated with aviation. The author advanced an argument that the greatest potential for long-term efforts to reduce the risk of collisions between aircraft and birds lies in the design of safe airframe structures and engines which disperse as well as absorb energy created by the impact. This, accompanied by the development of ground-based and aircraft systems which, facilitate monitoring and prediction of bird behaviour, will which assist ground personnel and air crew in decision-making.

Keywords: aircraft safety, aircraft, costs, birds, collision

Type of article: review article

\section{Аннотация}

Цель: Определение угроз, связанных с последствиями столкновений воздушных судов с птицами, а также представление социальных и финансовых последствий таких происшествий.

Введение: Столкновения воздушных транспортных средств с малыми объектами являются серьёзной проблемой, которая касается безопасности пассажиров, грузов и технических приборов. Среди случаев такого типа преобладают происшествия с участием птиц. В статье представлены угрозы, которые в авиации вызывают столкновения воздушных судов с птицами и другими объектами, с которыми случайно может столкнуться быстро движущийся самолёт, находящийся в воздухе или на взлётной полосе.

Методология: Явление, известное как Foreign Object Damage, представлено в историческом понятии с акцентом на новые тренды и тенденции, которые образуются в современных технических, природных и организационных реалиях. В представленной работе был проведен анализ причин, повышающих вероятность событий, влияющих на возможный удар птицы в элементы конструкции воздушного судна. Рассмотрены также вопросы, указывающие на большой риск столкновения, связанные с увеличением воздушных перевозок и адаптацией птиц к условиям окружающей среды вокруг аэропортов. В статье представлена информация, касающаяся числа столкновений и их взаимосвязи с определёнными причинами. Анализ был проведен для данных, касающихся гражданской и военной авиации, с особым вниманием к информации, полученной из США и Великобритании. Представлены методы ограничения риска возникновения столкновения воздушного судна с птицей. Рассмотрена надёжность и экономическая эффективность действий, которые проводятся с целью управления окружающей средой на территории аэропортов. Было подчёркнуто, какую роль в ограничении риска выполняют международные законы, устанавливающие минимальные нормы, требования и процедуры, регулирующие принципы проектирования, производства, технического обслуживания и использования авиационного оборудования, а также лицензирования персонала.

Выводы: В статье указано, что столкновения воздушных судов с птицами являются глобальной проблемой и касаются всех субъектов, связанных с авиацией. Констатирован факт, что самый большой потенциал в долгосрочных действиях, направленных на снижение угрозы столкновения с птицей - это развитие безопасных конструкций фюзеляжей и двигателей, рассеивающих и поглощающих энергию удара, а также наземных и бортовых систем, позволяющих проводить мониторинг и прогнозировать поведение птиц, помогая наземному персоналу и экипажу воздушного судна в принятии решений.

Ключевые слова: безопасность полётов, самолёты, расходы, птицы, столкновения,

Вид статьи: обзорная статья

\section{Wstęp}

Kolizje statków powietrznych z ptakami towarzyszą rozwojowi awiacji od momentu pierwszych lotów ostatecznie zatwierdzających obecne status quo związane $\mathrm{z}$ podziałem przestrzeni powietrznej pomiędzy ptaki i sztuczne załogowe lub bezzałogowe maszyny latające o napędzie wymuszonym. Pierwszy wypadek został odnotowany już przez braci Wright 7 września 1905 r. w czasie prób jedynego w owym czasie prototypu samolotu o charakterze użytkowym Flyer III [1]. Podczas wykonywania lotu kołowego maszyna pilotowana przez Orvile'a Wrighta wleciała w klucz ptaków, zabijając jednego $\mathrm{z}$ nich. W rezultacie uderzenia uszkodzeniu uległ element układu sterowania znajdujący się na górnym płacie maszyny. Pierwszy tragiczny wypadek będący następstwem kolizji z mewą wydarzył się w 1912 r. na Long Beach w Kalifornii, w którym podczas lotu pokazowego samolotu Wright Model B - Pusher zginął amerykański pionier awiacji, pilot Cal Rodgers [2]. Od tego czasu obecność maszyn latających w powietrzu stała się elementem życia codziennego i stanowi nieustanne źródło problemów wynikających $\mathrm{z}$ ingerencji człowieka $\mathrm{w}$ naturalne ptasie środowisko.

\section{Przyczyny kolizji}

Zderzenia z ptakami, popularnie określane w języku angielskim jako bird strike, stanowią główny, ale nie jedyny problem związany z kolizjami statków powietrznych. Zewnętrzne struktury samolotu są narażone także na uderzenia twardych odłamków pasa startowego, gumowych odłamków opon oraz zderzenia z mniejszymi lub większymi zwierzętami lądowymi. Jednak te zagrożenia w odróżnieniu od ptaków występują tylko w czasie ruchu samolotu po pasie startowym. Nie bez znaczenia są także zjawiska atmosferyczne wywołujące niebezpieczeństwo zarówno w czasie startu, jak i lotu. Uderzenia gradu, który może osiągać wielkość piłek golfowych, powodują uszkodzenia bezpośrednio zagrażające integral- 
ności struktury statku, często kończące się jego całkowitym zniszczeniem.

Ze względu na różnorodność przyczyn zderzeniowych, w których uderzenie ciała obcego powoduje uszkodzenie konstrukcji samolotu, mają one wspólną nazwę w języku angielskim: FOD - Foreign Object Damage. Pomimo występującego zróżnicowania przyczyn kolizji, znaczący procent, czyli ok. 90\% tego typu uszkodzeń samolotów, bezpośrednio powodują ptaki [3],[4].

Obecnie wszystkie dostępne wyniki badań wskazują, że zagrożenie spowodowane ptakami stale wzrasta w związku z trzema zasadniczymi powodami.

Pierwotne przyczyny tkwią w globalizacji, której jednym $z$ rezultatów jest nieustannie zwiększające się natężenie ruchu powietrznego [5]. Potwierdza to liczba lotów, która tylko na terenie USA wzrosła z $18 \mathrm{mln}$ w $1980 \mathrm{r}$. do $28 \mathrm{mln}$ w roku 2008. Dodatkowo amerykańska Federal Aviation Administration (FAA) przewiduje, że w roku 2025 liczba lotów tylko w ruchu cywilnym osiągnie poziom $35 \mathrm{mln}$ startów [6].

Drugą przyczyną jest gwałtowny w ostatniej dekadzie wzrost ptasiej populacji spowodowany szybką adaptacją dzikich ptaków do warunków życia w terenie zurbanizowanym, w tym także w okolicach lotnisk. Od roku 1980 do 2007 populacja gęsi kanadyjskiej na terenie USA i Kanady wzrosła $\mathrm{z}$ jednego do czterech milionów. Podobna sytuacja występuje w przypadku mew [7, 8]. Dzikie ptaki zmodyfikowały swoje zachowania i tolerują zarówno obecność człowieka, jak i urządzeń technicznych. Z tego powodu bardzo ciężko jest wyeliminować ich obecność w otoczeniu lotnisk. Są to miejsca najbardziej niebezpieczne, ponieważ największe prawdopodobieństwo wystąpienia kolizji samolotu $\mathrm{z}$ ptakiem zachodzi podczas startu i lądowania zwłaszcza wczesnym rankiem i późnym popołudniem [9]. Statystycznie $72 \%$ zderzeń ma miejsce blisko ziemi na wysokości poniżej $170 \mathrm{~m}, 87 \%$ jest efektem kolizji na wysokości poniżej 600 m, zaś 92\% to zajścia poniżej $1000 \mathrm{~m}$.

Nieco więcej kolizji jest odnotowywanych podczas lądowania niż podczas startu - prawdopodobnie dlatego, że podczas tego manewru samolot emituje mniej hałasu [10]. Jednak to właśnie podczas startu zaraz po oderwaniu występuje najbardziej niebezpieczny moment lotu, w którym gwałtowna utrata mocy spowodowana kolizją lub zassaniem ptaka do silnika może spowodować katastrofę. Chociaż wypadki na niskich wysokościach zaistniałe w okolicach lotnisk należą do najczęstszych, to najbardziej katastrofalne w skutkach są kolizje z dużymi ptakami na dużych wysokościach daleko od lotnisk. W tych przypadkach energia uderzenia wywoływana masą ptaka, dużą rejsową prędkością samolotu oraz brakiem możliwości szybkiego lądowania niemal zawsze powoduje ogromne zniszczenia w strukturze płatowca i w konsekwencji prowadzi do nieuchronnej utraty samolotu i ofiar śmiertelnych.

Trzecią przyczyną paradoksalnie powodującą wzrost prawdopodobieństwa kolizji samolotów z ptakami jest postęp techniczny w konstrukcji samolotów. Wprowadzenie samolotów o napędzie odrzutowym szczególnie wpłynęło na pogorszenie wskaźników bezpieczeństwa, gdyż kolizje z ptakami są niezwykle groźne dla tego rodzaju jednostek napędowych. Najczęściej dochodzi do mechanicznego uszkodzenia łopatek sprężarki, czy też łopatek wentylatora [11]. Współczesne samoloty są znacznie cichsze od swoich poprzedników i w większości mają jedynie dwa silniki. Dzięki nowoczesnym konstrukcjom płatowca i silników zarówno człowiek, jak i ptaki oraz inne zwierzęta lądowe obecnie znacznie słabiej słyszą zbliżający się samolot. Charakterystyczna dla nowoczesnych konstrukcji mniejsza liczba silników to większe prawdopodobieństwo całkowitej utraty mocy w wyniku uszkodzenia przez FOD ruchomych elementów zespołu napędowego. Ze względu na mniejszą liczbę silników współczesne samoloty są bardziej wrażliwe na tego rodzaju zagrożenia niż ich wielosilnikowe starsze odpowiedniki. Nowoczesne silniki odrzutowe są znacznie bardziej efektywne niż konstrukcje pochodzące $\mathrm{z}$ trzech ostatnich dekad XX w. Cechą charakterystyczną nowych rozwiązań są znacznie większe wloty powietrza, co powoduje, że ich czołowa powierzchnia jest bardziej podatna na ptasią ekspozycję lub inne rodzaje ciał obcych. Średnica wentylatora $\mathrm{w}$ niektórych konstrukcjach, takich jak silnik GE 90-92B osiąga wartość 3,4 metra [12]. Dla dwuprzepływowych wentylatorowych silników odrzutowych stosowanych $\mathrm{w}$ samolotach pasażerskich i transportowych, odporność na zderzenia z ptakami związana jest głównie $\mathrm{z}$ wytrzymałością łopatek wentylatora. W samolotach wojskowych, których silniki są zabudowane w kadłubie, istotne jest prawidłowe uformowanie kanału dolotowego. Ptak może wytracić znaczną część swojej energii poprzez zderzenia ze ścianami tego kanału ze względu na skomplikowany kształt osi kanału i jego przekrojów poprzecznych [13],[14].

Także zamocowanie silników ma wpływ na poziom zagrożenia ze strony ptaków. Zebrane dane wskazują, że silniki zamocowane na ogonie (np. w samolotach DC-10, MD-11) charakteryzują się nieco mniejszym narażeniem niż silniki znajdujące się w gondolach pod skrzydłami, ponieważ są częściowo chronione przez skrzydła samolotu [6].

Silniki nie są jedynymi elementami statku powietrznego zagrożonymi kolizją z FOD. Do poważnych uszkodzeń dochodzi także na dziobie, w oknach kabiny pilotów, krawędziach natarcia skrzydeł, stateczników, klapach, podwoziu oraz gondoli silnika [15]. Każda szkoda powstała w tych obszarach może bezpośrednio wpływać na sterowność i właściwości lotne samolotu. Niemniej jednak silniki są elementami częściej podlegającymi uszkodzeniom niż wynikałoby to tylko $\mathrm{z}$ ich powierzchni czołowej. W ich przypadku nawet wróbel może powodować odkształcenie plastyczne krawędzi natarcia łopatki wentylatora, naruszając jego aerodynamikę. Uderzenie gęsi wywołuje całkowite pęknięcia rdzenia łopatki lub jej rozerwanie, co powoduje dalsze nieodwracalne zniszczenia w układzie napędowym.

Skutki zderzeń z ptakami stanowią realne zagrożenie dla życia załogi statku i pasażerów, a ich poważne konsekwencje stają się coraz bardziej znaczące. Dzieje się tak, ponieważ nowoczesne samoloty pasażerskie przewożą na swoim pokładzie coraz więcej osób i nawet drobne uszko- 
dzenie spowodowane ciałem obcym może łatwo wywołać niezwykle tragiczny łańcuch wydarzeń.

Od czasów pionierskich lotnictwa prawdopodobieństwo wystąpienia kolizji z ptakiem oraz bezwzględna liczba wypadków stale wzrasta. Zgodnie z informacjami FAA w 2008 roku na terenie USA zarejestrowano 7516 zdarzeń, zaś ogólna liczba udokumentowanych przypadków pomiędzy 1990 r. a 2008 r. wynosi 89727 [16]. Ponadto tylko w 2011 r. U.S. Air Force dodatkowo poinformowały o 4500 zderzeń $F O D$ zarejestrowanych dla amerykańskich samolotów wojskowych [7],[8],[17]. W ciągu ostatnich 19 lat liczba wypadków lotniczych związanych z ptakami zwiększyła się ponad czterokrotnie [18], co potwierdzają także dane krajowe np. z USA (ryc. 1).

Wiąże się to z ogromnym wzrostem zagrożenia bezpieczeństwa pasażerów. Od 1990 r. Federalna Agencja Awiacji zbiera raporty dotyczące martwych ptaków znalezionych w elementach struktury samolotów. Według raportów w ciągu 19 lat wystąpiło ponad 100 tys. podobnych incydentów [20].

Informacje dotyczące kolizji samolotów z ptakami $\mathrm{z}$ całą pewnością są niepełne i dodatkowo zależą od regionu świata i państwa, w którym występują. Dane z niektórych obszarów są jedynie szczątkowe. Szacuje się, że nawet w USA jedynie co piąty przypadek jest oficjalnie rejestrowany, a kolizja statku powietrznego z ptakiem zachodzi średnio raz na dwa tysiące lotów. Średnio na 10 tys. lotów przypada od 8-19 zderzeń w zależności od regionu świata.

Należy zauważyć, że pomimo tak dużej liczby zderzeń samolotów z ptakami poważne uszkodzenia kadłuba lub silników powoduje jedynie 14-15\% wypadków z udziałem ptaków. Znacznie rzadsze, ale o wiele bardziej destruktywne są zderzenia ze zwierzętami lądowymi. Ze względu na większą masę ssaki powodują znaczne uszkodzenia struktury płatowca w aż $60 \%$ zdarzeń, które zachodzą na pasie startowym. W latach 1990-2005 na terenie lotnisk USA zarejestrowano 652 kolizje samolotu z sarnami oraz 198 zdarzeń z udziałem kojotów [21]. Zagrożenie na pasie startowym stanowią także gady. W latach 19902011 w Stanach Zjednoczonych odnotowano 137 kolizji statków powietrznych z krokodylami [19]. Bez wątpienia to jednak ptaki stanowią podstawowy problem w konflikcie pomiędzy kierowanymi statkami powietrznymi i dziką przyrodą.

\section{Straty materialne i niematerialne}

Spektakularne wypadki spowodowane ptakami, o ile są wydarzeniami stosunkowo rzadkimi, to jednak ogólnie stanowią w lotnictwie problem charakteryzujący się wysokim poziomem ryzyka. W przypadku konstrukcji lotniczych każde uderzenie ciała obcego w strukturę płatowca lub w silnik obniża jego zdolność do przenoszenia obciążeń eksploatacyjnych i może stanowić bezpośrednią przyczynę katastrofy.

W okresie od 1912 do 2008 r. w co najmniej 103 wypadkach cywilnych samolotów spowodowanych ptakami zginęło 276 osób w 54 katastrofach ze skutkami śmiertelnymi. Światową statystykę poważnych wypadków lotniczych spowodowanych kolizją z ptakami w pierwszej dekadzie XXI wieku obrazuje rycina 2.

Całkowitemu zniszczeniu uległo 108 samolotów [23, 24]. Dotychczas w największej katastrofie samolotu cywilnego Lokheed Electra L-188, spowodowanej zderzeniem z ptakami w dniu 4 października 1960 r. zginęły 62 osoby. W szóstej sekundzie po starcie do trzech turbośmi-

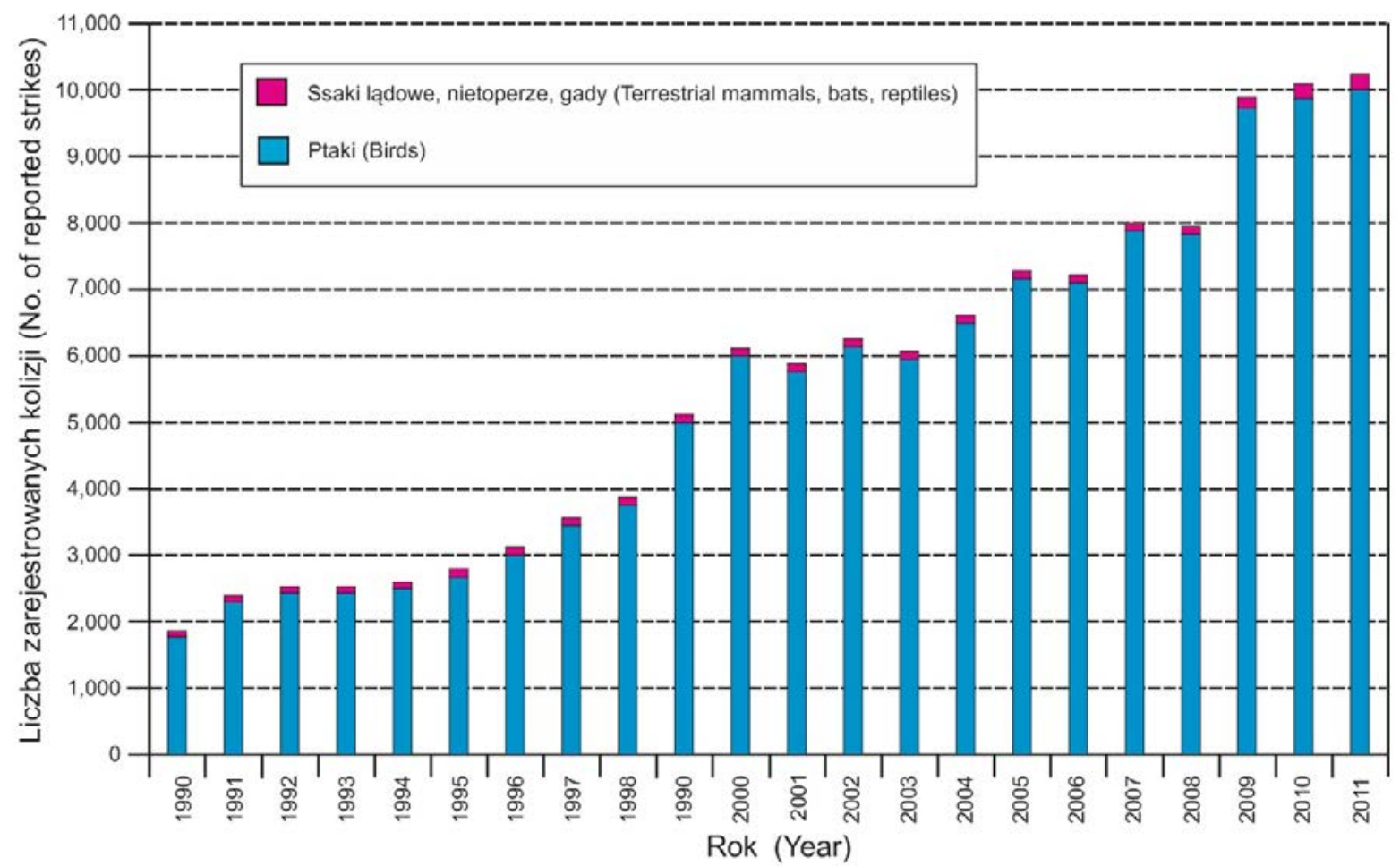

Ryc. 1. Liczba zarejestrowanych kolizji samolotów z ptakami w USA w latach 1990-2007 [19]

Fig. 1. Number of reported wildlife strikes with civil aircraft, USA, 1990-2011 [19] 


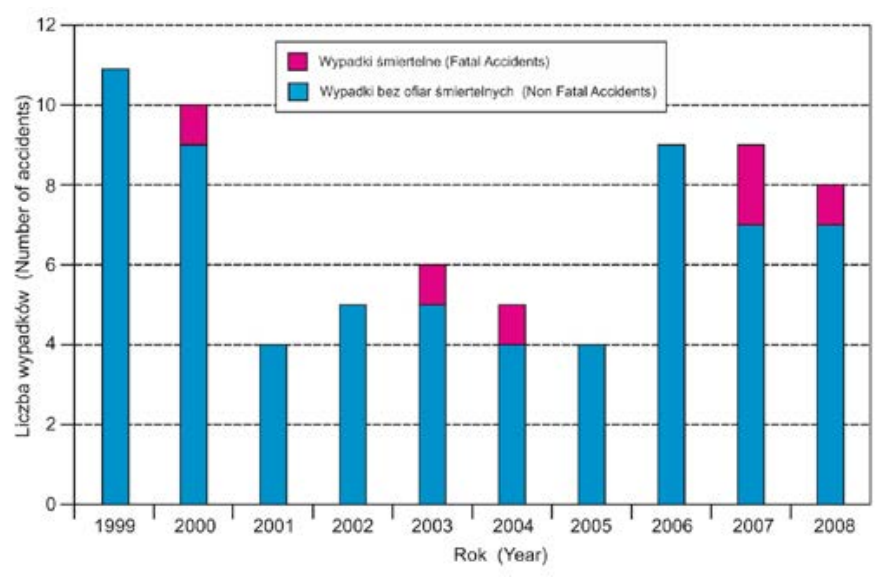

Ryc. 2. Światowa liczba wypadków spowodowanych kolizją statku powietrznego z ptakiem w latach 1999-2008 [22]

Fig. 2. Number of accidents due to a bird strike worldwide (1999-2008) [22]

O znaczącym wzroście zagrożenia świadczy liczba 195 ofiar śmiertelnych zarejestrowanych jedynie od roku 1988.

Duże odrzutowe samoloty pasażerskie i transportowe w całym okresie istnienia $\mathrm{z}$ powodu ptaków uległy 15 tragicznym katastrofom, w których zginęło 188 osób, a 42 zaginęły. W tej grupie maszyn jeden wypadek śmiertelny wynikający z kolizji z FOD zdarza się średnio co $1,4 \mathrm{mln}$ godzin lotu. $Z$ tych samych przyczyn samoloty o masie poniżej $5700 \mathrm{~kg}$ uległy 32 wypadkom, w których zginęło 70 osób, a 56 uznano za zaginione. W tym czasie kolizje z ptakami przyczyniły się do 7 katastrof helikopterów cywilnych, które pochłonęły 18 ofiar, a zniszczeniu uległo 9 maszyn.

Mała liczba wypadków w grupie helikopterów, pomimo niskiego pułapu lotu tych statków powietrznych, wynika z mniejszych prędkości przelotowych i większego hałasu generowanego przez silnik i rotor. Przewiduje się jednak, że trendy związane $\mathrm{z}$ budową cichszych i szybszych helikopterów spowodują w przyszłości wzrost tragicznych kolizji o $60 \%$, zwłaszcza po uderzeniu dużego ptaka w okno kabiny pilotów.

Szczególnie w lotnictwie wojskowym ze względu na niestandardowo niski pułap lotu oraz jednosilnikowe konstrukcje myśliwców prawdopodobieństwo tragicznej w skutkach kolizji z ptakiem jest bardzo wysokie [3]. Większość najnowszych wypadków maszyn wojskowych zdarzyła się podczas lotów z dużymi prędkościami, co w decydującym stopniu zwiększało rozmiar zniszczeń i redukowało szanse przeżycia lub bezpiecznego lądowania.

Pierwsze zarejestrowane straty sił powietrznych dotyczą jeszcze samolotów z silnikami tłokowymi wykorzystywanymi w służbie RAF (Royal Air Force), które przed 1950 r. z powodu ptaków straciły 39 maszyn. Potwierdzona utrata pierwszego samolotu o napędzie odrzutowym miała miejsce w 1952 r. Był nim dwusilnikowy myśliwiec Meteor, w którym wystąpiła nienaprawialna awaria powstała wskutek zassania ptaka do silnika i wywołanego w ten sposób pożaru [25]. Istnieją jednakże nie w pełni udokumentowane raporty informujące, że pierwszym odrzutowcem zniszczonym na skutek kolizji z ptakiem był niemiecki myśliwiec Messerschmitt Me 262 Schwalbe - pierwszy użyty bojowo samolot myśliwski o napędzie odrzutowym - 28 października 1944 roku.

Lotnictwo brytyjskie w swojej historii zanotowało 108 poważnych wypadków z udziałem ptaków. Wypadkiem poważnym jest nazywane zdarzenie kończące się nienaprawialną awarią samolotu, jego stratą lub ofiarami śmiertelnymi. Spośród tych wypadków w RAF 39 zdarzyło się przed rokiem 1950, 44 w latach 1950-1979 i 25 w latach 1980-2004. W latach 1980-2008 tylko w lotnictwie wojskowym USA zginęło siedmiu pilotów, a czternaście maszyn uległo zniszczeniu w wyniku uderzenia ptaka w statek powietrzny [25],[26].

Liczba kolizji samolotów wojskowych z ptakami ma tendencję wzrostową, nawet jeżeli w latach 19902000 w wielu krajach nastąpiła znacząca redukcja lotów. W tym czasie w siłach powietrznych wielu państw wystąpiło wiele przypadków utraty jedno- i dwusilnikowych myśliwców odrzutowych i samolotów treningowych oraz trzykrotna strata samolotów czterosilnikowych. Katastrofy te pochłonęły ogółem 58 ofiar śmiertelnych.

Także w Polsce np. w 2007 roku odnotowano 16 zderzeń samolotów cywilnych z ptakami, zaś w 2006 roku zarejestrowano 15 kolizji w lotnictwie wojskowym [11].

Wraz z rozwojem technologii problemy utraty maszyn z powodu ptasich kolizji zaczęły dotyczyć także samolotów bezzałogowych. Potwierdza to zdarzenie z 19 lipca 2011 r., gdy amerykański dron został zniszczony w Pakistanie w trakcie lotu nad rafinerią po przypadkowym zderzeniu z ptakiem [16].

O ile utrata sprzętu chociaż niezmiernie kosztowna jest jednak wymierna i relatywnie łatwo odtwarzalna, o tyle straty ludzkie oprócz oczywistych ludzkich tragedii osobistych w kategoriach wojskowych stanowią zasoby bardzo trudne do uzupełnienia. Całkowite straty ludzkie w lotnictwie wojskowym, których przyczyny wiążą się z FOD, są trudne do precyzyjnego oszacowania. Według danych udostępnionych przez 32 państwa Europy centralnej i zachodniej oraz Kanadę, USA, Izrael, Australię i Nową Zelandię w latach 1950-1999 miały miejsce 283 poważne wypadki zakończone utratą samolotu [25]. W tej liczbie 63 były wypadkami tragicznymi, które pochłonęły 141 ofiar śmiertelnych stanowiących 25 załóg pokładowych. Z wymienionych 283 wypadków maszyn wojskowych 179 to jednosilnikowe myśliwce $\mathrm{z}$ napędem odrzutowym (wśród których 141 było pilotowanych jednoosobowo), 40 myśliwców dwusilnikowych oraz 17 szkolnych samolotów odrzutowych jednosilnikowych i 17 dwusilnikowych.

Kraje, których lotnictwo wojskowe w tych latach poniosło największe straty sprzętu spowodowane kolizją z ptakami, to Wielka Brytania (66 strat), USA (62), Niemcy (34), były ZSRR (26) i Kanada (18). O ile dane dostarczone $\mathrm{z}$ krajów zachodnich są wiarygodne, o tyle informacje pochodzące $\mathrm{z}$ byłego ZSRR są $\mathrm{z}$ całą pewnością niekompletne.

Kolizje motorowych statków powietrznych z ptakami są związane nie tylko $\mathrm{z}$ bezpieczeństwem załóg pokładowych i pasażerów, ale także z ogromnymi kosztami, które muszą ponosić przedsiębiorstwa w związku z naprawą uszkodzonych maszyn lub utratą wpływów. 
Bird Strike Committee USA informuje, że ptaki oraz inne przyczyny związane z FOD powodują roczne straty wynoszące ponad 600 milionów dolarów w całej cywilnej i wojskowej sferze transportu lotniczego. Zakres przestojów wywołanych z tego powodu wśród samolotów cywilnych waha się od 95000 do 580000 godzin rocznie przy założeniu, że jedynie co piąty przypadek jest zgłaszany w USA [27]. W lotnictwie wojskowym wydarzenia z udziałem ptaków generują w US Air Forces roczne koszty na poziomie $50 \div 80$ mln dolarów (włączając straty samolotów), zaś według danych United Kingdom Royal Air Force (RAF) opracowanych przez RAF Inspectorate of Flight Safety roczne koszty lotnictwa brytyjskiego w tym obszarze wynoszą 23,3 mln USD. Wojskowe statystyki podają także, że ptaki chociaż czasami nie stanowią bezpośredniej przyczyny katastrofy, to często leżą u jej źródeł, ponieważ zmuszają pilota do wykonania niebezpiecznych manewrów w celu ominięcia przeszkody. W US Air Forces zanotowano siedem wypadków zakończonych katastrofą spowodowanych próbą uniknięcia zderzenia i gwałtownym omijaniem ptaka [28].

W skali światowej straty lotnictwa cywilnego spowodowane kolizjami z ptakami wynoszą 1,3 mld dolarów rocznie, co generuje dodatkowe koszty około 64,50 USD na każdy lot. Stanowi to duży problem zarówno dla linii lotniczych, jak i firm ubezpieczeniowych wypłacających znaczne odszkodowania. Przykładowo jeden wypadek kończący się jedynie wymianą silnika wywołuje dodatkowe koszty średnio na poziomie $5 \mathrm{mln}$ USD. Ale już w przypadku samolotu Boeing 777 nakłady na wymianę silnika PW4098 każdorazowo przekraczają 15 mln dolarów. Bezpośrednie koszty napraw to jedynie niewielka część kosztów całkowitych. Ogromne znaczenie mają nieprzewidywalne opóźnienia wynikające z przymusowego uziemienia uszkodzonego samolotu. Zakłada się, że każde pierwotne opóźnienie samolotu, który uległ kolizji, wywołuje cztery wtórne opóźnienia lub wtórne odwołania kolejnych samolotów. Każde opóźnienie pierwotne wywołuje straty równe 75 tys. USD, co w następstwie pociąga koszty opóźnienia lub odwołania wtórnego wynoszące 35 tys. USD przypadające na każdą pojedynczą zmianę planu lotów. Duża amerykańska linia lotnictwa cywilnego tylko w jednym roku zarejestrowała 1326 kolizji z ptakami. Całkowity koszt naprawy uszkodzonego sprzętu wyniósł w tej firmie 6,2 mln USD. Koszty wynikające z opóźnień i odwołań oszacowano na poziomie 46,45 mln USD. Ogółem roczne straty przedsiębiorstwa $\mathrm{z}$ tego powodu wyniosły $52,650 \mathrm{mln}$ USD, co w przeliczeniu daje wskaźnik 39,71 USD na jedną kolizję. Obliczenia przeprowadzane alternatywną metodą określiły 64,50 USD jako dodatkowe koszty związane z każdą ptasią kolizją samolotu.

\section{Ograniczanie ryzyka}

Służby lotnicze oraz producenci samolotów podejmują działania zmierzające do ograniczenia poziomu ryzyka wywoływanego przez ptaki. W celu zapobiegania skutkom kolizji zasadnicze znaczenie mają trzy podstawowe kierunki działania.
Pierwszym stosunkowo najprostszym do wprowadzenia jest działanie prewencyjne polegające na ograniczaniu prędkości lotu samolotów na małych wysokościach. Współczesne samoloty bez trudu na małych wysokościach rozwijają prędkości 320-340 węzłów względem powietrza [knots indicated airspeed (KIAS)]. Od 2003 roku w USA i Kanadzie wprowadzono zakaz przekraczania prędkości 250 węzłów do wysokości 10000 stóp (3000 $\mathrm{m})$. Do tej grupy dołączył Meksyk i teraz zakaz obowiązuje w całej Ameryce Północnej [29]. Ograniczenia te zostały również $\mathrm{w}$ późniejszym okresie wprowadzone na terenie wielu innych państw (całkowicie lub na wydzielonych obszarach). Działanie zapewnia szybkie i łatwe do obliczenia efekty bezpośrednie, ponieważ zwiększenie prędkości o $20 \%$ z 250 do 300 KIAS powoduje $44 \%$ wzrostu energii podczas kolizji z ptakiem. Oznacza to, że gęś o masie 5 kg na wysokości 90000 stóp przy prędkości 250 KIAS wywołuje uderzenie $\mathrm{z}$ siłą $36000 \mathrm{~kg}$ zaś przy prędkości 300 KIAS siła uderzenia wzrasta do $50000 \mathrm{~kg}$. Wysokość 10000 stóp jest poziomem znajdującym się powyżej szlaków migracji większości ptaków, które w swoich przelotach przemieszczają się zazwyczaj w korytarzu na wysokościach pomiędzy 5000 a 7000 stóp. Poziom 10000 stóp został określony jako bezpieczny także ze względu na ograniczenia wzajemnej kolizji między statkami powietrznymi.

Drugim działaniem zmierzającym do zmniejszenia w lotnictwie zagrożenia wywoływanego przez ptaki, jest odpowiednia kontrola lotnisk i terenów przyległych w celu ograniczenia liczby ptaków. Prowadzone są operacje, np. za pomocą środków chemicznych, mających za zadanie likwidację wysokiej roślinności sprzyjającej rozwojowi ptasich siedlisk. Utrzymanie niskiego poziomu trawy, likwidacja drzewostanu oraz pobliskich żerowisk występujących w postaci rozlewisk lub składowisk odpadów utrudnia przebywanie ptakom w okolicach lotnisk. Niestety ptaki szybko adoptują się do nowego środowiska i skuteczność tych działań jest ograniczona. Podobnie w przypadku innych działań odstraszających, polegających na stosowaniu hukowych środków pirotechnicznych, broni palnej, środków akustycznych, instalacji oświetleniowych czy środków chemicznych w postaci gazów, pestycydów i herbicydów ich skuteczność z czasem maleje, ponieważ ptaki przyzwyczajają się do zmiany środowiska i przestają reagować na powtarzające się bodźce.

Stwierdzono także, że koszenie wysokiej trawy powoduje wzrost dostępu ptaków do miejsc bogatych w zasoby pokarmu (głównie bezkręgowce i gryzonie), do których dotychczas dostęp był utrudniony. Usunięcie barier wizualnych $\mathrm{w}$ postaci roślinności powoduje polepszenie komfortu żerującym. Na przykład na lotnisku w Dęblinie koszenie trawy latem powoduje silny wzrost liczebności: krukowatych (gawron, kawka, sroka), siewkowatych (czajka, kulik wielki) oraz mew (śmieszka). Pokosy zwabiają również szpaki i dzierzby. Koszenie ułatwia żerowanie bocianom białym oraz ptakom szponiastym wyspecjalizowanym w chwytaniu gryzoni (myszołowy, pustułki, błotniaki) [30]. W związku z komplikacjami, jakie może powodować koszenie trawy, obecnie zaleca się sia- 
nie specjalnych gatunków traw o wysokościach uniemożliwiających żerowanie ptactwa na terenie lotniska.

Najnowszą skuteczną metodą stosowaną w nocy i o zmierzchu jest odstraszanie ptaków za pomocą promieni lasera emitowanych $\mathrm{w}$ postaci wielometrowych wiązek przez obracające się głowice. Pomimo dużej różnorodności technik ograniczania obecności ptaków na lotniskach każda z nich jest działaniem kosztownym. Wg danych Royal Air Force Strike Command roczne koszty pielęgnacji trawy lotnisk wojskowych są szacowane na poziomie 80 -250 tys. USD. Roczne utrzymanie służb odpowiedzialnych za odstraszanie ptaków na jednym lotnisku w USA wynosi średnio od 25-150 tys. USD. W Wielkiej Brytanii RAF oszacował koszty programu kontroli ptaków na lotniskach w kwocie 200 tys. USD rocznie na jedno lotnisko. Działania te przynoszą jednak wymierne efekty.

Przykładem skuteczności programów kontroli ptaków jest projekt wdrożony na lotnisku Kennedy'ego w USA. Pierwotnie dochodziło tam do 300 przypadków kolizji rocznie, które kosztowały linie lotnicze wykorzystujące lotnisko 11,4 mln USD [31]. Po uruchomieniu projektu z udziałem biologów, ekip strzeleckich oraz sokolników liczba zderzeń samolotów z ptakami została ograniczona do tego stopnia, że stosunek oszczędności do kosztów wyniósł 39:1. Na innym amerykańskim lotnisku notującym rocznie 170 kolizji, po wprowadzeniu ekip strzeleckich liczba zderzeń po roku wynosiła jedynie 50 zarejestrowanych przypadków. 170 kolizji powodowało dodatkowe 4,6 mln USD kosztów dla linii lotniczych, natomiast program strzelecki kosztował 120 tys. USD. W przeliczeniu koszt jednego zderzenia to kwota 27 tys. USD. Zatem program zwrócił się już po eliminacji pięciu zderzeń.

Bardzo obiecującą metodą płoszenia ptaków jest wykorzystywanie do tego celu psów rasy Border Collie. Metoda została opracowana i wdrożona w 1999 r. w USA na lotnisku Southwest Florida International Airport. Do tej pory program ten wprowadzono na trzech komercyjnych lotniskach w USA i dwóch w RPA (Durban i Johannesburg) oraz w trzech bazach wojskowych (Dover $A F B$, Cold Lake AFB, Israeli Air Force) [32]. Metoda ta po raz pierwszy została także zastosowana na łódzkim lotnisku im. W. Reymonta. W efekcie zredukowano o ok. 30\% liczbę obserwowanych ptaków (kosów i wron) oraz ograniczono o ok. 50\% liczbę obserwowanych ptaków brodzących [33],[34].

Elementem zmniejszania ryzyka kolizji statków powietrznych z ptakami jest określenie stref bezpieczeństwa wokół lotnisk. Są to strefy zarezerwowane dla ruchu lotniczego zawierające korytarze startu i lądowania [35]. Nad tymi obszarami lądujący samolot znajduje się na wysokości od ok. 150 do $300 \mathrm{~m}$ (strefa podejścia: od 3 do $6 \mathrm{~km}$ od progu pasa drogi startowej) oraz poniżej $150 \mathrm{~m}$ (strefa lądowania: od progu pasa drogi startowej do $3 \mathrm{~km}$, czyli do początku strefy podejścia). Strefy rozciągają się także na ok. $2 \mathrm{~km}$ po bokach pasa drogi startowej [36]. Pod względem bezpieczeństwa lotniczego najistotniejsza jest strefa podejścia znajdująca się na przedłużeniu pasa startowego. Jest to obszar, w którym odnotowuje się 80-85\% kolizji z ptakami. Wprowadzony podział bazuje na świa- towych danych o udziałach liczby kolizji z ptakami odnotowanych na poszczególnych wysokościach. Najważniejsza jest strefa zagrożenia bezpośredniego rozciągająca się do pułapu $500 \mathrm{~m}$ i odległości do koło $9 \mathrm{~km}$ od progu pasa startowego. Wg wymagań ICAO oraz standardów IBSC optymalna strefa bezpieczeństwa obejmuje także trzynastokilometrowy okrąg wokół lotniska [37],[38].

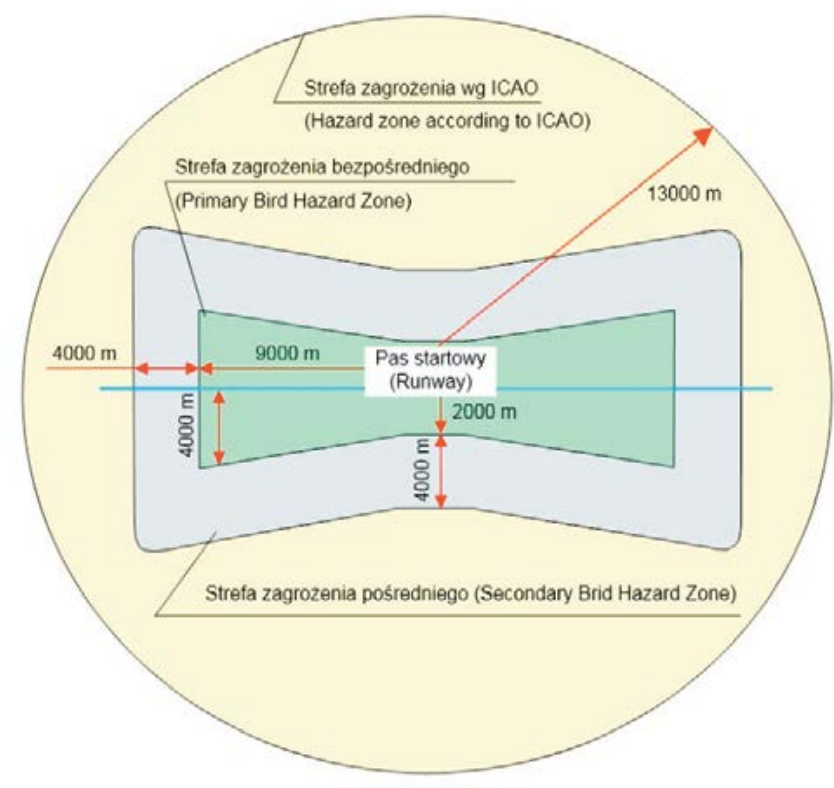

Rys. 3. Strefa zagrożenia [36],[37],[38]

Fig. 3. Hazard zone [36],[37],[38]

Podział na strefy związany jest z koniecznością identyfikacji miejsc koncentracji ptaków oraz siedlisk mogących przyciągać ptaki [39]. Dodatkowo zwraca się jednak uwagę na konieczność analizy warunków lokalnych, uwzgledniającej obecność zbiorników wodnych czy też wysypisk śmieci oddalonych o ponad $13 \mathrm{~km}$, poza strefą lotniska, które mogą mieć wpływ na bezpieczeństwo operacji lotniczych.

Trzecim rodzajem działań zmierzających do poprawy bezpieczeństwa lotów jest budowa płatowców i silników w sposób zmniejszający ryzyko katastrofalnych uszkodzeń wywoływanych na skutek kolizji z ptakami. Działania te są regulowane za pomocą przepisów odpowiednich władz lotnictwa cywilnego określających właściwe wymagania i wytyczne dla producentów.

Agencjami odpowiedzialnymi za przygotowywanie odpowiednich przepisów i koordynację działań są US Federal Aviation Admionistrations (FAA), European Joint Aviation Authorities s (JAA) oraz European Aviation Safety Agency (EASA).

Zarówno amerykańskie przepisy lotnicze FAR $(\mathrm{Fe}$ deral Aviation Regulations), jak i europejskie JAR (Jonit Aviation Requirements) i CS (Certification Standards) definiują minimalne normy, wymagania i procedury regulujące zasady projektowania, produkcji, obsługi technicznej, użytkowania sprzętu lotniczego oraz licencjonowania personelu. W grudniu 1991 r. ECC (European Community Commission) przyjęła wymagania JAR jako wyłączne źródło przepisów lotnictwa cywilnego obowiązujące w Unii Europejskiej. Rezultatem współpracy FAA 
i JAA było przyjęcie tej samej numeracji co w FAR podstawowych wymagań JAR. Również nadzór lotniczy Rosji (MAK) zdecydował się na tworzenie własnych przepisów AP (Aviacjonnyje Prawiła) opartych na przepisach FAR, wprowadzając podobne zasady harmonizacji pomiędzy MAK i FAA, które funkcjonują pomiędzy JAA i FAA.

Każda $\mathrm{z}$ organizacji lotniczych $\mathrm{w}$ ramach opracowanych przez siebie przepisów zawarła odpowiednie wymagania określające niezbędny poziom odporności konstrukcji płatowców i silników na zderzenie z ptakiem.

Szyby czołowe, owiewki lub wiatrochrony kabiny pilotów oraz konstrukcja podpierająca te elementy muszą wytrzymać uderzenie ptakiem o masie $1,8 \mathrm{~kg}$ bez skutków penetracji, przy prędkości samolotu względem ptaka określanej wzdłuż toru lotu równej prędkości rejsowej $\mathrm{V}_{\mathrm{C}}$ na poziomie morza (FAR/JAR/CS 25.775).

Dla krawędzi natarcia skrzydeł lub usterzenia ogonowego wymagane jest, aby nawet w przypadku penetracji poszycia nie powstały uszkodzenia krytyczne w innych elementach struktury skrzydła i usterzenia. Samolot poruszający się z prędkością rejsową $\mathrm{V}_{\mathrm{C}}$ po uderzeniu ptakiem o masie $1,8 \mathrm{~kg}$ w krawędź natarcia skrzydła lub ptakiem o masie 3,6 kg w krawędź natarcia usterzenia ogonowego musi bezpiecznie kontynuować lot i wykonać lądowanie (FAR/JAR/CS 25.571, 25.631).

Struktura wiropłata musi być tak zaprojektowana, aby zapewnić bezpieczne kontynuowanie lotu i lądowanie po zderzeniu z ptakiem o ciężarze $1 \mathrm{~kg}$ przy prędkości względem ptaka wzdłuż toru lotu równej maksymalnej prędkości w locie poziomym $\mathrm{V}_{\mathrm{H}}$ lub prędkości dopuszczalnej $\mathrm{V}_{\mathrm{NE}}$ na wysokościach do 8000 stóp (FAR/JAR/CS 29.631).

Dla siników turbinowych i turbowentylatorowych pochłonięcie małego ptaka o masie do $0,9 \mathrm{~kg}$ przy prędkości wzdłuż toru lotu równej $\mathrm{V}_{\mathrm{C}}$ na poziomie morza lub $0.85 \mathrm{~V}_{\mathrm{C}}$ na wysokości 8000 stóp nie może spowodować spadku mocy większego niż $25 \%$. Dla dużych ptaków o masie $1,8 \mathrm{~kg}$ musi zostać udowodnione, że silnik może być bezpiecznie wyłączony z odcięciem zasilania. Wlot silnika musi również wytrzymać uderzenie ptaka o masie 1,8 kg bez uszkodzenia elementów krytycznych (FAR/ JAR/CS 25.571, 33.76).

Zgodnie z przytoczonymi przepisami należy empirycznie udowodnić zdolność do kontynuowania lotu samolotów cywilnych i wojskowych za pomocą demonstracji dokumentujących spełnienie wymagań. Dlatego też przed dopuszczeniem do eksploatacji nowego typu samolotów konieczne jest wykonanie określonych w normach badań odporności na uderzenie elementów konstrukcji płatowca.

Badania prowadzone są na specjalnie zaprojektowanych do tego stanowiskach, umożliwiających miotanie ptaków lub ich sztucznych odpowiedników o odpowiedniej masie $\mathrm{z}$ wymaganą prędkością w kierunku badanej struktury [40-45]. Jest to tzw. „próba ptaka” (bird test) wykonywana zgodnie $\mathrm{z}$ zaleceniami zawartymi w przepisach FAR.

\section{Wnioski}

Kolizje samolotów z ptakami są nierozerwalnie związane zarówno $\mathrm{z}$ historią, jak i rozwojem awiacji w przyszłości. Chociaż zazwyczaj powodują jedynie drobne uszkodzenia, zawsze będą stanowić ogromne zagrożenie dla bezpieczeństwa lotów. Mimo wykorzystywania wielu metod zapobiegawczych oraz zaawansowanego zarządzania środowiskiem przyrodniczym wypadki z udziałem ptaków będą zdarzać się nadal, zwłaszcza że lotniska stają się coraz bardziej ruchliwe i zatłoczone, a częstotliwość lotów wzrasta z każdym rokiem. Zmiany środowiskowe wywołujące ewolucję w zachowaniu ptaków oraz wzrost ich liczebności spowodują nieuchronne zwiększenie zainteresowania ptasiej populacji terenami wokół lotnisk. Coraz więcej ptaków będzie zasiedlać tereny, gdzie ich obecność spowoduje nasilenie niebezpiecznych sytuacji w ruchu powietrznym. Porty lotnicze muszą być w stałej gotowości, wykorzystując coraz nowsze techniki odstraszania i monitoringu ptaków oraz zwierząt naziemnych. Piloci i kontrolerzy lotów muszą być świadomi zagrożeń, które może wywołać kolizja statku powietrznego z ptakiem i stosować się do stale doskonalonych procedur umożliwiających redukcję ryzyka i konsekwencji wynikających z zagrożenia ptasią kolizją. Kolizje te są problemem globalnym i dotyczą wszystkich podmiotów związanych z lotnictwem, włączając pilotów, mechaników, linie lotnicze, operatorów lotnisk, kontrolerów ruchu, personel pokładowy, personel zarządzania środowiskiem, władze lotnicze, a także - a może przede wszystkim - producentów i konstruktorów statków powietrznych. Skoro zmiany w przyrodzie są nieuniknione i odstraszanie ptaków z czasem będzie zadaniem coraz trudniejszym o malejącej efektywności, oznacza to, że największy potencjał w zachowaniu standardów bezpieczeństwa lotów tkwi w rozwoju bezpiecznych konstrukcji płatowców i silników. Wszystkie części struktury samolotów i helikopterów muszą być projektowane tak, aby rozpraszać energię uderzenia i odchylać trajektorię uderzającego obcego obiektu w celu ochrony konstrukcji płatowca i silników w przypadku kolizji z ptakiem. W celu spełnienia tych wymagań wytrzymałościowe własności szyb, owiewek, wiatrochronów, skrzydeł, łopatek turbin, usterzenia ogonowego oraz podwozia muszą być weryfikowane za pomocą intensywnych testów prowadzonych doświadczalnie i na drodze symulacji cyfrowej. Równie istotnym i być może kluczowym zagadnieniem jest doskonalenie i rozwój pokładowych oraz naziemnych systemów umożliwiających monitoring i predykcję ptasich zachowań systemów wspomagających personel naziemny i załogi statków powietrznych w podejmowaniu właściwych decyzji wykorzystujących radarową kontrolę ruchu.

\section{Literatura}

1. Sharing the skies. An Aviation Industry Guide to the Management of Wildlife Hazard, Transport Canada, 2004.

2. Thorpe J., Fatalities and destroyed civil aircraft due to bird strikes, 1912-2002 International Bird Strike Committee, Warsaw 2003.

3. Heimbs S., Computational methods for bird strike simulations: A review, "Computers and Structures", Vol. 89, Issues 23-24, 2011, pp. 2093-2112. 
4. Zbrowski A., Bezpieczeństwo samolotów w aspekcie zagrożenia kolizją z ptakami. „Problemy Eksploatacji”, Issue 2, 2012, pp. 215-228.

5. Meguid S, Mao R, Ng T., FE Analysis of geometry effects of an artificial bird striking an aeroengine fan blade, "International Journal of Impact Engineering", Vol. 35 Issue 6, 2008, pp. 487-498.

6. Aircraft Technology Engineering \& Maintenance, Vol. 107, August-September 2010.

7. Cleary E., Dolbeer R., Wright S., Wildlife Strikes to Civil Aircraft in the United States 1990-2005, Bird Strike Committee Proceedings, 2006.

8. Dolbeer R., i inni, Wildlife Strikes to Civil Aircraft in the United States 1990-2009, Report of The Associate Administrator For Airports, Office of Airport Safety and Standards Airport Safety \& Certification. Federal Aviation Administration, No. 16, Washington, DC May 2011.

9. Airoldi A., Cacchione B., Modelling of impact forces and pressures in Lagrangian bird strike analyses, "International Journal of Impact Engineering", Vol. 32, 2006, pp. 16511677.

10. Hou J.P., Ruiz C., Soft body impact on laminated composite materials, "Composites Part A: Applied Science and Manufacturing", Issue 1, 2007, pp. 505-515.

11. Szczeciński S., Balicki W., Głowacki P., Uszkodzenia silników turbinowych wywołane zderzeniami z ptakami, „Przegląd Sił Powietrznych", Issue 2, 2009, pp. 15-21.

12. The GE90 - An Introduction, [dok. elektr.] http://www.stanford.edu/ cantwell/AA283_Course_Material/GE90_Engine_Data.pdf [dostęp 01.04.2014].

13. Boguszewicz P., Sala S., Wloty powietrza turbinowych silników odrzutowych i ich wplyw na właściwości lotne samolotów oraz zagrożenia bezpieczeństwa latania, Prace Instytutu Lotnictwa, Vol. 213, Warszawa 2011, s. 101-111.

14. Balicki W., Chachurski R., Głowacki P., Kozakiewicz A., Szczeciński J., Szczeciński S., Wloty powietrza turbinowych silników odrzutowych i ich wplyw na wlaściwości lotne samolotów oraz zagrożenia bezpieczeństwa latania, Prace Instytutu Lotnictwa Vol. 213, Warszawa 2011, s. 47-54.

15. Heimbs S., Bird Strike Simulations on Composite Aircraft Structures, SIMULIA Customer Conference, Barcelona, May 17-19, 2011, s. 73-86.

16. Park C., Jang B., Kim J., Kim C., Jun S.: Bird strike event monitoring in a composite UAV wing using high speed optical fiber sensing system, "Composites Science and Technology”, Vol. 72 Issue 6, 2012, pp. 498-505.

17. Airoldi A., Cacchione B., Modelling of impact forces and pressures in Lagrangian bird strike analyses, "International Journal of Impact Engineering", Vol. 32 Issue 10, 2006, pp. 1651-1677.

18. Bird Strike Damage\&Windshield Bird Strike Final Report, European Aviation Safety Agency, 2009.

19. Wildlife strikes to civil aircraft in the United States 19902011, Report of The Associate Administrator Of Airports Office of Airport Safety and Standards Airport Safety \& Certification Washington, DC, 2012.

20. Georgiadis S., Gunnion A., Thomson R., Cartwright B., Bir$d$-strike simulation for certification of the Boeing 787 composite moveable trailing edge, "Composite Structures", Vol. 86 Issues 1-3, 2008, pp. 258-268.

21. DeVault T., Kubel J., Glista D., Rhodes O., Mammalian hazards at small airports in Indiana: impact of perimeter fencing, "Human-Wildlife Conflicts", Vol. 2 Issue 2, 2008, pp. 240-247.

22. Maragakis I., Bird population trends and their impact on Aviation safety 1999-2008, European Aviation Safety Agency, 2009.

23. Thorpe J., Fatalities and destroyed civil aircraft due to bird strikes 1912-2002, Bird Strike Committee Proceedings. Warsaw, Poland, May 2003.
24. Thorpe J., Update on fatalities and destroyed civil aircraft due to bird strikes with appendix for 2006-2008, Bird Strike Committee Proceedings, Brazil, November 2008.

25. Richardson W., West T., Serious birdstrike accidents to U.K. military aircraft, 1923 to 2004: Numbers and circumstances, Bird Strike Committee Proceedings, Athens, May 2005.

26. Klich E., Bezpieczeństwo lotów, Wydawnictwo Naukowe Instytutu Technologii Eksploatacji - PIB, Radom, 2011.

27. Allan J., Orosz A., The costs of birdstrikes to commercial aviation, Bird Strike Committee Proceedings, USA/Canada, Calgary, 2001.

28. Richardson W., Serious birdstrike-related accidents to military aircraft of ten countries: Preliminary analysis of circumstance, Bird Strike Committee Proceedings, Vienna, 1994.

29. Eschenfelder P., High speed flight at low altitude: hazard to commercial aviation, Bird Strike Committee Proceedings, Vancouver, 2005.

30. Ćwiklak J., Grzegorzewski M., Grzywaczewski G., Kitowski I., Jafernik H., Ptaki jako zagrożenie dla bezpieczeństwa lotów, „Logistyka”, Issue 3, 2012, pp. 38-390.

31. Allan J., The costs of bird strikes and bird strike prevention, Human Conflicts with Wildlife: Economic Considerations, 8-1-2000, pp. 146-153.

32. Froneman, A. and Rooyen, M., The successful implementation of a border collie bird scaring program at Durban International Airport, South Africa, International Bird Strike Committee, Warsaw 2003, [dok. elektr.] http://www.intbirdstrike.org/Warsaw_Papers/IBSC26\%20WPAE1.pdf [dostęp 17.03.2014].

33. Implementacja metody Border Collie na łódzkim lotnisku, [dok. elektr.] http://www.ulc.gov.pl/_download/lotniska/komitet_zderzenie_ze_zwierzetami/BC-\%C5\%81\%C3\%B$3 \mathrm{~d} \% \overline{\mathrm{C}} 5 \%$ BA.pdf [dostęp 18.03.2014].

34. Łódź Lublinek: Border Collie odstraszy ptaki, http://www. latajznami.pl/branzowe,5710,lodz_lublinek_border_collie_ odstraszy_ptaki.html [dostęp 05.04.2014].

35. Skakuj M, Kitowski I, Łukasik D., Wpływ ruchu lotniczego na ptaki. Część I, „Ornis Polonica”, Vol. 55, 2014, pp. 48-68.

36. Sowden R., Kelly T., Dudley S., Airport Bird Hazard Risk Assessment Process, Transport Canada, 2007.

37. Podręcznik Stużb Portu Lotniczego, część 3. Kontrola $i$ zmniejszanie zagrożén ze strony zwierząt, International Civil Aviation Organization, 2012.

38. Standards for Aerodrome Bird/Wildlife Control. Recommended Practice No. 1 International Bird Strike Committee, 2006.

39. Skakuj M., Szmit P.: Ptaki, lotniska, samoloty - określenie konfliktu, [dok. elektr.] http://www.ulc.gov.pl/ download/ bezpieczenstow_lotow/biuletyny/2012/opracwanie_0612. pdf [dostęp 08.04.2014].

40. Zbrowski A, Majcher A.: Mechatronic System for Impact Tests for Aero Structures, "Solid State Phenomena. Mechatronic Systems and Materials IV', Vol. 198, 2013, pp. 366371 .

41. Zbrowski A., Samborski T., Zacharski S., Badania odporności zderzeniowej szybkich środków transportu z matymi obiektami, „Pomiary Automatyka Robotyka PAR”, Vol. 11, 2012, pp. 59-67.

42. Zbrowski A., Działo pneumatyczne do testów zderzeniowych, „Problemy Eksploatacji”, Issue 3, 2012, pp. 133-144.

43. Zbrowski A., Experimental tests concerning the impact resistance of a tailplane. "Archives of Civil and Mechanical Engineering", Vol. 14 Issue 1, 2014, pp. 53-60.

44. Zbrowski A., Instrumentarium badawcze do testów zderzeniowych konstrukcji lotniczych, BiTP, Vol. 35 Issue 3, 2014, pp. 61-71.

45. Zbrowski A., Samborski T., Zacharski S., The method for high-energy throwing of the objects in impact testing, "TTS Technika Transportu Szynowego", Issue 9, 2012, pp. 619627. 
dr inż. Andrzej Zbrowski - w 1993 roku ukończył studia na Wydziale Mechanicznym Wyższej Szkoły Inżynierskiej w Radomiu. W roku 2000 uzyskał stopień doktora na Wydziale Samochodów i Maszyn Roboczych Politechniki Warszawskiej. Adiunkt w Instytucie Technologii Eksploatacji - PIB w Radomiu. Kieruje Zakładem Doświadczalnym. Koncentruje się na zagadnieniach związanych z budową maszyn, konstrukcjami mechatronicznymi urządzeń badawczych oraz systemami bezpieczeństwa technicznego. Jest autorem lub współautorem ponad 250 publikacji naukowych, 71 uzyskanych patentów oraz 160 zgłoszeń patentowych. Brał udział w realizacji 55 projektów badawczych, ponadto kierował 15 projektami badawczymi, zamawianymi, celowymi, rozwojowymi i własnymi. 